\title{
SENSITIVITY ANALYSIS ON THERMOHYDRAULIC CODE FOR MODIFIED PLATE-FUELED 2 MW TRIGA
}

\author{
Endiah Puji Hastuti, Surip Widodo \\ Center for Reactor Technology and Nuclear Safety - BATAN \\ Kawasan Puspiptek Serpong Gd.80, Tangerang Selatan, Banten 15314 \\ e-mail: endiah@batan.go.id \\ (Naskah diterima: 13-11-2018, Naskah direvisi: 17-12-2018, Naskah disetujui: 22-01-2019)
}

\begin{abstract}
SENSITIVITY ANALYSIS OF THERMOHYDRAULIC CODE FOR MODIFIED PLATE-FUELED

2 MW TRIGA. The plan to modify TRIGA 2000 Bandung from using regular TRIGA fuel to platetype fuel should be supported by the use of appropriate computer codes. This research proposes three codes to design reactor thermohydraulics at transient condition. Analysis has been performed to identify code sensitivity using the same input and correlation. The codes used were COOLOD-N2, Heathyd, and PARET-ANL. The input was obtained from preliminary analysis of a flow rate calculation of $70 \mathrm{~kg} / \mathrm{s}$ and a nominal power of $2 \mathrm{MW}$. The comparison of these three codes did not consider uncertainty factor for neutronic and technical aspects. The sensitivity analysis on thermohydraulic codes used to calculate heat transfer in the fuel plate of TRIGA reactor at steady state condition indicates similar temperature trend lines for the coolant, plate, and fuel meat. Temperature calculation results obtained from COOLOD-N2, Heathyd and PARET ANL give consistent sensitivity with the differences of coolant temperature from $2.83 \%$ to $12.5 \%$; cladding temperature from $2.14 \%$ to $31.30 \%$; and fuel meat temperature from $6.63 \%$ to $18.64 \%$. The margins of flow instability were 5.03; 5.68 and 4.21, respectively for COOLOD-N2, Heathyd, and PARET-ANL. These values show that flow instability has not yet occurred. The results of the analysis show that the use of those three codes for steady state condition using the same input, in which uncertainty factor is neglected, give similar trend for coolant, cladding, and fuel meat temperature. As the modelling in each code is different, the values obtained are not exactly the same.
\end{abstract}

Keywords: sensitivity analysis, TRIGA Plate, COOLOD-N2, Heathyd, PARET-ANL. 
ABSTRAK

ANALISIS SENSITIVITAS PROGRAM THERMOHIDROLIKA PADA MODIFIKASI REAKTOR TRIGA BERBAHAN BAKAR TIPE PELAT 2 MW. Rencana modifikasi reaktor TRIGA 2000 Bandung dari bahan bakar TRIGA menjadi tipe pelat, perlu didukung dengan penggunaan program komputasi yang tepat. Pada penelitian ini dipilih tiga program untuk mendesain termohidrolika pada kondisi tunak. Analisis digunakan untuk mengetahui sensitivitas program, menggunakan input dan pemilihan korelasi yang sama. Program komputasi yang digunakan di sini adalah COOLOD-N2, Heathyd dan PARET-ANL. Input yang digunakan berasal dari analisis awal perhitungan laju alir sebesar $70 \mathrm{~kg} / \mathrm{s}$ dan daya nominal $2 \mathrm{MW}$. Upaya untuk membandingkan ketiga program ini tidak digunakan faktor ketidakpastian baik perhitungan neutronik maupun faktor-faktor teknis. Hasil perhitungan temperatur yang diperoleh dari program komputasi COOLOD-N2, Heathyd dan PARET ANL menghasilkan sensitivitas dengan nilai deviasi temperature pendingin 2,83\% hingga 12,5\%; temperatur kelongsong 2,14\% hingga 31,30\%; dan temperatur bahan bakar 6,63\% hingga 18,64\%. Sementara itu, marjin keselamatan terhadap instabilitas aliran masing masing sebesar 5,03; 5,68 dan 4,21, pada perhitungan COOLOD-N2, Heathyd, dan PARET-ANL, nilai tersebut menunjukkan bahwa instabilitas aliran belum terjadi. Hasil analisis menunjukkan bahwa penggunaan program perhitungan steady state dengan input yang sama, dimana faktor ketidakpastian diabaikan menghasilkan trend line temperatur pendingin, kelongsong dan fuel meat yang sama. Pemodelan pada tiap program komputasi berbeda sehingga menghasilkan nilai yang tidak tepat sama.

Kata kunci: analisis sensitivitas, TRIGA Pelat, COOLOD-N2, Heathyd, PARET-ANL 


\section{INTRODUCTION}

In order to extend the reactor life time, Bandung TRIGA reactor is now being modified. The modification is applied to the reactor fuel type without the change in the reactor nominal power, i.e. $2 \mathrm{MW}$. The change in fuel type from UZrH cylindrical type to $\mathrm{U}_{3} \mathrm{Si}_{2} / \mathrm{Al}$ fuel plate with low enrichment of $2.96 \mathrm{gU} / \mathrm{cm}^{3}$ will alter cooling mode from natural to forced convection. The cooling mode in the plate fuelled TRIGA occurs in forced convection with downward flow. Meanwhile, natural convection cooling mode takes place when loss of flow accident (LOFA) occurs or when reactor physic experiments are carried out. The reactor core is designed to have $5 \times 5$ lattice with grid geometry of $81 \mathrm{~mm} \times 77.1 \mathrm{~mm}$, consisting of 16 assemblies of fuel plate, 4 control elements, and 5 irradiation positions [1]. This new core configuration does not change the core geometry initially filled with rod-type fuel. Several independent researcher have been performed in order to design fuel plate TRIGA. Prasetyo et al. (2014) conducted a preliminary analysis on neutronic aspect of the modified TRIGA using Monte Carlo code (MCNP)[2]. Anwar et al. (2017) compared the preliminary calculation results of coolant flow rate in the MTR fuel type using computational fluid dynamic (CFD) code[3]. Subekti et al. also conducted modeling and analysis of the RSG GAS fuel temperature profile using CFD[4]. Sujatmi et al. (2015) carried out preliminary analysis on natural convection mode using COOLOD-N2 [5]. In addition, Hastuti EP also conducted an analysis of primary and secondary cooling system at high power reactor design[6]. Hastuti EP et al. (2017) performed an analysis on flow rate distribution using Caudvap [7].

There are several calculation codes that can be employed in designing fuel plate TRIGA thermohydraulic. Therefore, sensitivity analysis on these codes should be carried out first through benchmarking process, i.e. computer code test. In this research, The selected codes are used to analyze thermohydraulic and safety parameters of forced convection cooling mode at steady state condition. The analysis on these codes are done based on the same inputs and correlation as far as possible. The test conducted does not consider uncertainty factor at steady state condition, but uses power distribution obtained from the results of neutronic calculation. The codes used are COOLOD-N2, Heathyd and PARET-ANL. These codes have been used to analyze fuel plate research reactor designs. Al Yahia et al. (2016) performed transient analysis for $5 \mathrm{MW}$ Jordan reactor using COOLOD-N2 [8]. Meanwhile, Ardaneh et al. (2013) carried out analytical solution for thermal-hydraulic analysis and safety margins in MTR-type research reactors cooled by natural convection using CONVEC V 3.40 computer code [9]. Al Yahia et al (2013) conducted transient thermal hydraulic analysis of the IAEA 10MW MTR reactor during Loss of Flow Accident to investigate the flow inversion [10]. Hastuti et al. used PARET ANL to analyze RIA accidents in the design of highpower research reactors [11], meanwhile Rubina et al. (2013) conducted study of successive ramp reactivity insertions in typical pool-type research reactors[12]. From the analysis carried out above, there has not been seen a sensitivity assessment of the steady state thermohydrolics program, which is used to analyze forced convection heat transfer modes in the modified TRIGA plate reactor design. Therefore in this study a comparative analysis of selected codes using the same input and the selection of the same correlation were carried out. The analysis results obtained from these codes will provide confidence on the applicability and sensitivity of the codes used to design the thermohydraulic of modified fuel TRIGA reactor core. 


\section{METHODOLOGY}

\section{a. TRIGA Plate modified}

The modified fuel of TRIGA 2000 Bandung is plate-type with density of $2.96 \mathrm{gU} / \mathrm{cm}^{3}$ fabricated by PT. INUKI. This type of fuel has been utilized by GA Siwabessy reactor since 2002. The reactor consist of 16 fuel elements plate type, 4 control rods and 5 irradiation position. Each fuel element consist of 21 fuel plates, meanwhile control element consist of 15 plates with blades in each sides. The reactor core is placed in a reactor pool with graphite reflectors using demineralized water as coolant. Primary cooling water transfers the heat produced by the fuel by forced convection in the downward direction. The configuration of the reactor core of fuel plate TRIGA is shown in Figure 1 and the main reactor and fuel data are shown in Table 1.

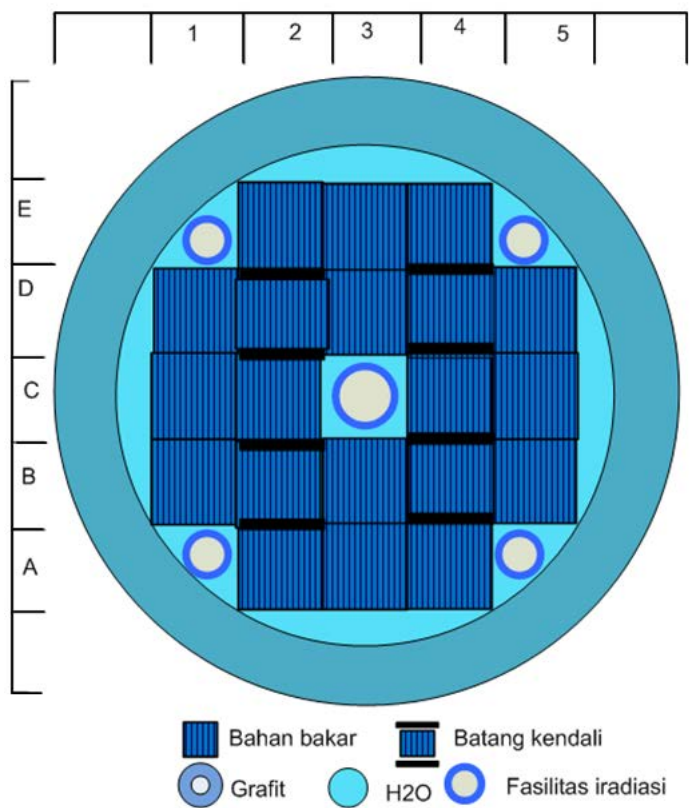

Figure 1. TRIGA Plate core configuration design $[1,5]$.

Table 1. Main data of modified TRIGA plate reactor $[1,5]$.

\begin{tabular}{lc}
\hline & Parameter \\
\hline Reactor power, MW & 2 \\
Reactor Pool & \\
Pool height, $m$ & 8.5 \\
Reactor core position under the pool water level, $\mathrm{m}$ & 5.5 \\
Reactor pool diameter, $\mathrm{m}$ & 1.9812 \\
Reactor core & \\
Matrix grid & $5 \times 5$ \\
Geometry grid, mm & $81 \times 77.1$ \\
Standard fuel element & \\
Number of standard fuel element & 16 \\
Number of plate & 21 \\
Number of coolant channel & 20 \\
Fuel element cross section geometry, mm & $75.7 \times 67.1 \times 51.5$ \\
Coolant channel gap, mm & 2.55 \\
Plate geometry, length $x$ width $x$ thick, mm & $625 \times 70.75 \times 1.3$ \\
Meat geometry, length $x$ width $x$ thick, mm & $600 \times 62.75 \times 0.54$ \\
Control Element & \\
Number of control elements & 4 \\
Number of plate & 15 \\
Number of coolant channel & 14 \\
\hline
\end{tabular}




\section{b. TRIGA Plate modified}

As described above, the computer codes benchmarked, COOLOD-N2, Heathyd, and PARET-ANL, have thermohydraulic calculation for steady state condition. In addition to transient calculation, PARET-ANL can be used to solve hydrodynamic and point kinetic calculation. The techniques of analysis and the scope of these codes are shown in Table 2.

Table 2. Thermal hydraulic computer codes for steady state analysis [5,11-12].

\begin{tabular}{|c|c|c|c|}
\hline No. & Computer codes & Technical analysis & Scope \\
\hline 1. & COOLOD-N2 & $\begin{array}{l}\text { The COOLOD-N2 is developed } \\
\text { based on the COOLOD-N code and } \\
\text { provides a capability for the analysis } \\
\text { of the steadystate thermal- } \\
\text { hydraulics of research reactors. The } \\
\text { COOLOD-N2 is applicable for } \\
\text { research reactors in which plate- } \\
\text { type fuel, and rodtype (pin-type) fuel } \\
\text { are adopted. }\end{array}$ & $\begin{array}{l}\text { Calculating the coolant } \\
\text { temperature, and fuel } \\
\text { cladding both on condition of } \\
\text { forced convection neither on } \\
\text { natural convection, calculating } \\
\text { ONB temperature, the heat } \\
\text { flux at onset of flow instability } \\
\text { (for plate-type fuel only) as } \\
\text { well as DNB heat flux }\end{array}$ \\
\hline 2. & Heathyd & $\begin{array}{l}\text { Heathyd is a code for the steady- } \\
\text { state heat transfer calculation of } \\
\text { research nuclear reactors with } \\
\text { forced convection. It models heat } \\
\text { transfer and coolant flow for } \\
\text { assemblies of parallel fuel plates of } \\
\text { MTR type with any axial power } \\
\text { distribution The thermodynamic } \\
\text { model accounts for single phase } \\
\text { cooling and sub-cooled boiling } \\
\text { condition. }\end{array}$ & $\begin{array}{l}\text { Heathyd calculates axial } \\
\text { distribution of the coolant and } \\
\text { clad-surface temperatures. } \\
\text { Safety margins to the critical } \\
\text { heat flux as a result of burnout } \\
\text { condition or flow instability }\end{array}$ \\
\hline
\end{tabular}

The code determines the steady-state solution for the initial state and the transient by integration in time and space.

PARET/ANL is a thermal, hydrodynamic, and point kinetics calculation, based on a one-

3. PARET-ANL dimensional solution for a researchtype plate or rod-fueled reactor. The code was originally developed to model reactors cooled by an open loop, which was adequate for rapid transients in pool-type cores.
Multiple heat transfer, DNB and flow instability correlations are available. Temperature- and pressuredependent thermal properties of the coolant such as enthalpy, density, thermal conductivity, and viscosity are also used in determining parameters such as friction factors and heat transfer coefficients 
The correlations used by the three codes, are selected in accordance with the calculation to be solved. To obtain the test results of the codes, the same correlation should be selected first, as shown in Table 3.

Table 3. Correlations used in selected codes [5,11-12]

\begin{tabular}{|c|c|c|c|}
\hline \multirow{2}{*}{ Type of calculation } & \multicolumn{3}{|c|}{ Correlations } \\
\hline & COOLOD-N2 & Heathyd & PARET-ANL \\
\hline Saturation Temp. & Jeans Lottes & Jeans-Lottes & Jeans-Lottes \\
\hline $\begin{array}{l}\text { Single phase } \\
\text { downward flow }\end{array}$ & Dittus Boelter & Dittus-Boelter & $\begin{array}{l}\text { Dittus-Boelter } \\
\text { Sieder Tate }\end{array}$ \\
\hline $\begin{array}{l}\text { Heat flux single phase } \\
\text { and Two phase }\end{array}$ & - & - & $\begin{array}{l}\text { Mc Adam } \\
\text { Bergles Rosenow }\end{array}$ \\
\hline DNB heat flux and & Bernath & Mirshak-Labuntsov & Forgan FIR \\
\hline Flow Instability & Labuntsov & & CEA FIR \\
\hline ONB Temp & Bergles Rosenow & Bergles Rosenow & Bergles Rosenow \\
\hline OFIR & Whittle-Forgan & Forgan/Whittle & - \\
\hline $\begin{array}{l}\text { Friction correlation for } \\
\text { turbulent flow }\end{array}$ & $\begin{array}{l}\text { Blasius } \\
\text { Karman-Nikuradze } \\
\text { Colle-Brook }\end{array}$ & Blasius-Collebrook & - \\
\hline
\end{tabular}

The correlations used are varied for each code, as shown below:

Nusselt numbers for downward flow, one phase linear flow $(\operatorname{Re}<2000)$

$N u \equiv \frac{h \cdot D e}{k}=4.0$

Nusselt numbers for downward flow, one phase turbulent flow phase $(\operatorname{Re} \geq 2500)$ Dittus-Boelter correlation

$N u=0.023 \operatorname{Re}_{b}^{0.8} \operatorname{Pr}_{b}^{0.4}$

ONB heat transfer Bergles-Rohsenow correlation

$q=911 . P^{1.156}\left\{\frac{9}{5}\left(T_{O N B}-T_{S}\right)\right\}^{\frac{2.16}{P 0.1234}}$

Saturation nucleate boiling Chen correlation

$q=F .0 .023\left\{R e_{f}(1-x)\right\}^{0.8} \operatorname{Pr}_{b}^{0.4} \frac{k_{f}}{D e}\left(T_{w}-T_{s}\right)$

$+\mathrm{S} .7 .228 \frac{k_{f}^{0.79} C p_{f}^{0.45} \gamma_{f}^{0.49}\left(T_{w}-T_{S}\right)^{1.24}\left(P_{w}-P\right)^{0.75}}{\sigma^{0.5} \mu_{f}^{0.29} h_{f g}^{0.24} \gamma_{g}^{0.24}}$

(4)
$q_{D N B, 2}^{*}=\frac{A}{A_{H}} \frac{\Delta h_{i}}{h_{f g}}\left|G^{*}\right|$

where:

$\frac{1}{x_{t t}} \equiv\left(\frac{1}{1-x}\right)^{0.9}\left(\frac{\gamma_{f}}{\gamma_{g}}\right)^{0.5}\left(\frac{\mu_{g}}{\mu_{f}}\right)^{0.1}$

$F=1.0$ $\frac{1}{x_{t t}} \leq 0.1$

$F=2.35\left(\frac{1}{x_{t t}}+0.213\right)^{0.736} \quad \frac{1}{x_{t t}}>0.1$

$R e^{\prime} \equiv \frac{G(1-x) D e}{\mu_{f} g} \times 10^{-4}$

$S=\frac{1}{1+0.12 R e^{1.14}} \pi r^{2}$

$\mathrm{Re}^{\prime}<32.5$

$S=\frac{1}{1+0.42 R e^{0.78}}$

$32.5 \leq \operatorname{Re}^{\prime}<70.0$

$S=0.1$

$70.0 \leq \operatorname{Re}$

DNB heat flux

$q_{D N B, 1}^{*}=0.005\left|G^{*}\right|^{0.611}$

$q_{D N B, 3}^{*}=0.7\left(\frac{A}{A_{H}}\right) \frac{\left\{W\left(\frac{\gamma_{l}}{\sigma}\right)^{0.5}\right\}^{0.5}}{\left\{1+\left(\frac{\gamma_{g}}{\gamma_{l}}\right)^{0.25}\right\}^{2}}$ 
where:

$$
\begin{aligned}
& \text { A : flow area }\left(\mathrm{m}^{2}\right) \\
& A_{H}: \text { heated area }\left(\mathrm{m}^{2}\right) \\
& \mathrm{Cp} \text { : specific heat }\left(\mathrm{kcal} / \mathrm{kg}^{\circ} \mathrm{C}\right) \\
& \text { De : equivalen hydraulic diameter }(m) \\
& D_{H} \text { : heated equivalent diameter }(m) \\
& F \quad \text { : coefficient friction loss } \\
& F_{b} \text { : bulk temperature increment factor } \\
& F_{B} \text { : bond temperature increment factor } \\
& F_{f} \text { : film temperature increment factor } \\
& F_{u} \text { : fuel meat temperature increment } \\
& \text { factor } \\
& F_{w} \text { : cladding temperature increment } \\
& \text { factor } \\
& \mathrm{G} \text { : mass flow rate }\left(\mathrm{kg} / \mathrm{m}^{2} \mathrm{~s}\right) \\
& \text { non dimensional mass flow rate }= \\
& \mathrm{G}^{*}: \mathrm{G} / \lambda \cdot \gamma_{g} \cdot g\left(\gamma_{l}-\gamma_{g}\right) \\
& \text { g : gravitation acceleration }\left(\mathrm{m} / \mathrm{s}^{2}\right) \\
& \mathrm{h} \text { : heat transfer coefficient }\left(\mathrm{kcal} / \mathrm{m}^{2}\right. \\
& \left.\mathrm{h}^{\circ} \mathrm{C}\right) \\
& \mathrm{h}_{\mathrm{fg}}: \text { latent heat evaporation }(\mathrm{kcal} / \mathrm{kg}) \\
& \Delta \eta_{\mathrm{I}}: \text { inlet subcooled entalpi }(\mathrm{kcal} / \mathrm{kg}) \\
& \mathrm{k} \text { : thermal conductivity }\left(\mathrm{kcal} / \mathrm{m} \mathrm{h}^{\circ} \mathrm{C}\right) \\
& L \text { : flow channel length }(m) \\
& \mathrm{L}_{\mathrm{H}} \text { : heated length }(\mathrm{m}) \\
& \mathrm{Nu} \text { : Bilangan Nusselt } \\
& P \text { : Pressure }\left(\mathrm{kg} / \mathrm{cm}^{2}\right. \text { abs) } \\
& \mathrm{Pc} \text { : Peclet number } \\
& \mathrm{P}_{\mathrm{H}} \text { : heated perimeter }(\mathrm{m}) \\
& \mathrm{Pr} \text { : Prandtl number } \\
& q \text { : Heat flux }\left(\mathrm{kcal} / \mathrm{m}^{2} \mathrm{~h}\right)
\end{aligned}
$$

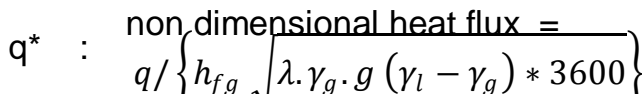

$$
\begin{aligned}
& \mathrm{Q} \text { : heat rate generation }(\mathrm{kcal} / \mathrm{h}) \\
& \mathrm{Re} \text { : Reynolds number } \\
& \mathrm{T} \text { : Temperature }\left({ }^{\circ} \mathrm{C}\right) \\
& \mathrm{v} \text { : velocity }(\mathrm{m} / \mathrm{s}) \\
& \text { W : channel width (m) } \\
& x \text { : quality } \\
& y \text { : width (m) } \\
& Z \text { : channel entrance distance }(m) \\
& \beta \text { : volumetric expansion coefficient } \\
& \left(1 /{ }^{\circ} \mathrm{C}\right) \\
& \varepsilon \text { : surface roughness }(\mathrm{m}) \\
& \mu \text { : dynamic viscosity }(\mathrm{kg} / \mathrm{m} \mathrm{s}) \\
& v \text { : kinematic viscosity }\left(\mathrm{m}^{2} / \mathrm{s}\right) \\
& \mathrm{Y}: \text { specific weight }\left(\mathrm{kg} / \mathrm{m}^{3}\right)
\end{aligned}
$$

friction coefficient due to
geometry change
Bubble detachment parameter
Subscript
bulk
bond
departure from nucleate boiling
film
gas
liquid
inlet
onset of nucleate boiling
saturation
sub cooled
fuel meat
wall/cladding

\section{c. Safety margin}

The reactor safety margin is designed to meet the safety in depth, i.e. to protect workers and public from radiation releases, which are contained by fuel cladding, by determining the maximum temperature allowed. The safety margin is needed to provide limitations on several operation condition, such as normal operation condition, in case the reactor power is inadvertently beyond and exceed its normal power. In addition, it is set to anticipate loss of flow accident. In other words, the safety margin is required for an unexpected accident that decreases the performance of heat transfer and should be anticipated. In the research reactor fuel assembly where the fuel gap is very narrow, onset of flow instability ratio (OFIR) caused by onset of nucleate boiling (ONB) should be avoided. Departure from nucleate boiling (DNBR) has also to be avoided. It occurs due to too high heat flux that cannot be lowered by the gap coolant flow and can cause dry out posing risk to the first fuel barrier, fuel cladding. The inlet temperature and coolant flow rate are factors that influence the safety margin. This safety margin include the onset of nucleate boiling (ONB), which should be $\geq 0{ }^{\circ} \mathrm{C}$, no OFIR, and DNBR $\geq 1.5$. 


\section{RESULTS AND DISCUSSION}

Uncertainty factor contributes significant impact to power peaking factor, which then raise the reactor safety margin. The safety margin is used to have flexibility required for the reactor operation. It is not easy to determine and apply the uncertainty factor. Large safety margin will limit the reactor operation. Experience in the reactor safety analysis can help to determine the precise uncertainty factor. In the sensitivity analysis of the codes, the uncertainty factor used is 1 or, in other words, the uncertainty factor is not considered in the calculation of axial and radial power peaking factor. The uncertainty factor $=1$ is applied to the three codes benchmarked

Axial power peaking factor used is the height of the control rod when the core reaches its criticality. The distribution of axial power peaking factor when the control rod at $42 \mathrm{~cm}$ high is shown in Figure 2.

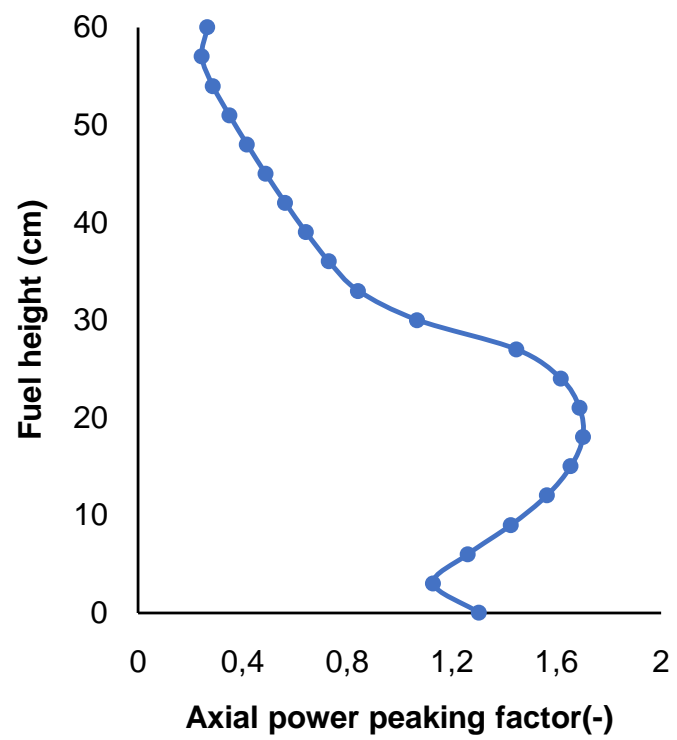

Figure 2. Axial power distribution across the active core $(0=$ bottom of the fuel plate).

The axial peak power distribution does not consider calculation uncertainty or it reflects the plain values. Similarly, the distribution of radial power peaking factor does not take into account the position and calculation uncertainty factor. It assumes that flux generation in the core is homogeneous. The average axial power peaking factor is 0.9831, while the highest axial power peaking factor is 1.699 when the control rod at $42 \mathrm{~cm}$ high above the upper core.

Table 3 present the input and calculation results using various codes. Flowrate distribution that passes through the active core is $88.2 \%$ of the permitted minimum flow of $70 \mathrm{~kg} / \mathrm{s}$. The input flowrate for the Heathyd program is needed to transfering heat from 1 fuel. Analysis of the calculation results for temperature coolant profiles, cladding and fuel meat are described in Figures 3 to 5 .

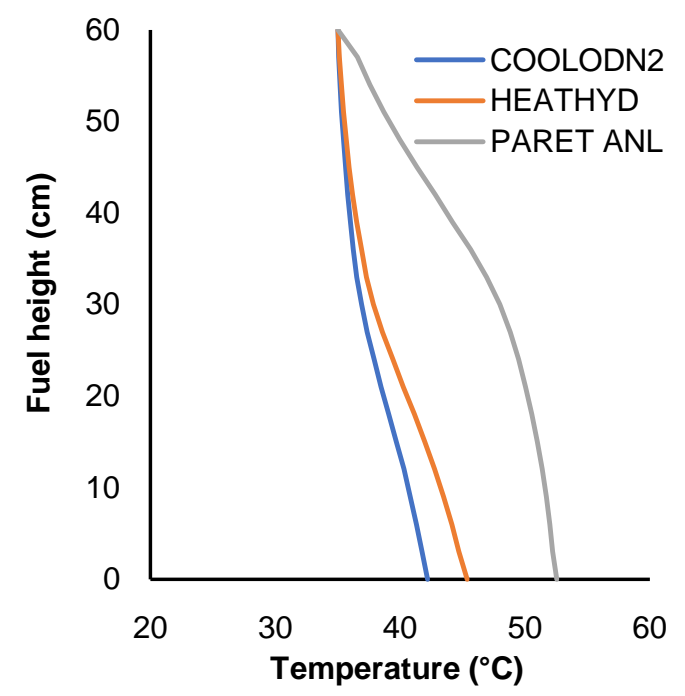

Figure 3. Comparison of coolant temperature.

Heat removal from the cladding to coolant occurs downward by forced convection with turbulent flow, Nu number for single phase downward turbulent $(\operatorname{Re} \geq 2500)$ and Dittus Boelter correlation. Figure 3 depicts the profile of coolant temperature distribution. COOLOD-N2 and Heathyd and PARET-ANL give outlet coolant temperature difference of $2.83 \%$ up to $12.5 \%$, the significant difference comes from PARET-ANL. In the modelling of PARET-ANL code, coolant flow rate is not only for transferring heat from the fuel, but also to cool all components on the reactor core, so the possibility of cooling through fuel is not exactly the same as compared to 
the other two programs. The profile of cladding temperature distribution is shown in Figure 4 . The trend line of produced by the three codes gives similar results, especially for temperature at the areas with distribution of axial high power peaking factor. For PARET-ANL, the model of heat transfer calculation is divided into 7 lateral nodes. Heat transfer from fuel meat to cladding considers steady state condition, in which the cladding temperature still has no reached its saturation. The cladding temperature difference for the three codes are $2.14 \%$ up to $31.30 \%$, Heathyd give smallest deviation in the maximum axial peaking factor, this is because heathyd modeling is more concentrated in heat transfer in just one fuel. Even though they generate similar trend line, PARET-ANL gives a more conservative calculation result.

Table 3. Calculation results using various codes.

\begin{tabular}{lccc}
\hline \multicolumn{1}{c}{ Parameter } & \multicolumn{3}{c}{ Codes } \\
\cline { 2 - 4 } & COOLOD-N2 & HEATHYD & PARET-ANL \\
\hline Reactor Power, MW & 2 & 2 & 2 \\
Tcoolant in, ${ }^{\circ} \mathrm{C}$ & 35 & 35 & 35 \\
Tcoolant out, ${ }^{\circ} \mathrm{C}$ & 42.18 & 45.37 & 52.53 \\
$\Delta$ T inlet-outlet, ${ }^{\circ} \mathrm{C}$ & 7.18 & 10.37 & 17.53 \\
$\mathrm{P}$ in, bar & 1.583 & 1.583 & 1.583 \\
Core Flowrate, $\mathrm{kg} / \mathrm{s}$ & 70 & - & 70 \\
\%Flowrate through active core, $\mathrm{kg} / \mathrm{s}$ & 88.2 & - & 88.2 \\
Flowrate through FE/CE, kg/s & 61.74 & - & 61.74 \\
Flowrate through 1 FE, kg/s & - & 2.8206 & - \\
FR, without multiplication factor & 1.000 & 1.000 & 1.000 \\
equilibrium core, $30 \mathrm{~cm}$ & & & \\
FA, without multiplication factor & 1.6990 & 1.6990 & 1.6990 \\
Engineering factor & 1.0000 & 1.0000 & 1.0000 \\
T cladding max., ${ }^{\circ} \mathrm{C}$ & 56.76 & 60.67 & 77.32 \\
T meat max., ${ }^{\circ} \mathrm{C}$ & 57.17 & 60.67 & 77.71 \\
T sat., ${ }^{\circ} \mathrm{C}$ & 113.15 & - & - \\
$\Delta \mathrm{P}$ accross the core, bar & 0.0217 & 0.0677 & - \\
$\Delta \mathrm{T}$ ONB, ${ }^{\circ} \mathrm{C}$ & 59.62 & 25.65 & 39.45 \\
DNBR & 6.18 & - & - \\
OFIR & 5.03 & 6.14 & 4.21 \\
T ONB, ${ }^{\circ} \mathrm{C}$ & 116.76 & 116.77 & 116.77 \\
\hline
\end{tabular}

At the initial calculation, the fuel meat temperature distribution produced by COOLOD-N2, Heathyd, and PARET-ANL is consistent with the trend line of cladding temperature distribution, since there is no distance between fuel meat and fuel cladding and their steady heat transfer makes no temperature difference. Meanwhile, for axial direction, heat transfer occurs in line with the distribution function of axial peak power and the distance/length of fuel meat. The fuel meat temperature difference calculated by COOLOD-N2, Heathyd and PARET-ANL are $6.63 \%$ up to $18.64 \%$.

The coolant flow rate is relatively low 0.93 to $0.96 \mathrm{~m} / \mathrm{s}$ with $3.1 \%$ difference, which is still below $10 \%$ indicating similarity. The safety margin analysis on flow instability for COOLOD-N2, Heathyd and PARET-ANL, each are, 5.03, 5.68 and 4.21, respectively. This shows that there is no flow instability in the sensitivity of TRIGA Plate analysis. 


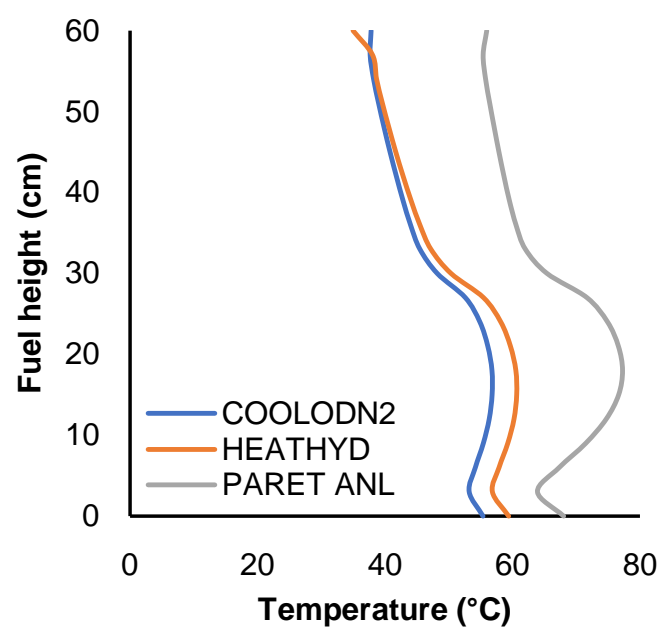

Figure 4. Comparison of cladding temperature profile

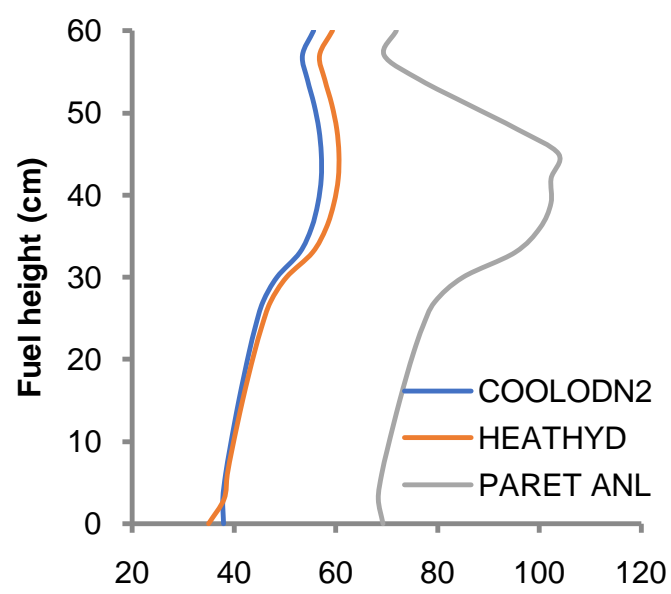

Fuel meat temperature $\left({ }^{\circ} \mathrm{C}\right)$

Figure 5. Comparison of fuel meat temperature profile.

Heathyd computer code provides detail thermohydraulic calculation results for each channel and fuel plate in a fuel element assembly, containing 21 plates and 20 coolant channel. The heat transfer calculation in Heathyd follows the axial power peaking distribution profile. The $11^{\text {th }}$ plate in the fuel element assembly has exactly the same fuel meat and cladding temperature profile, whereas the edge plate, i.e. the $18^{\text {th }}$ plate (from left to right), gives temperature profile with the same value. The configuration of fuel plate is shown in Figure 6 , while the temperature profile of the central and edge fuel plate is shown in Figure 7.

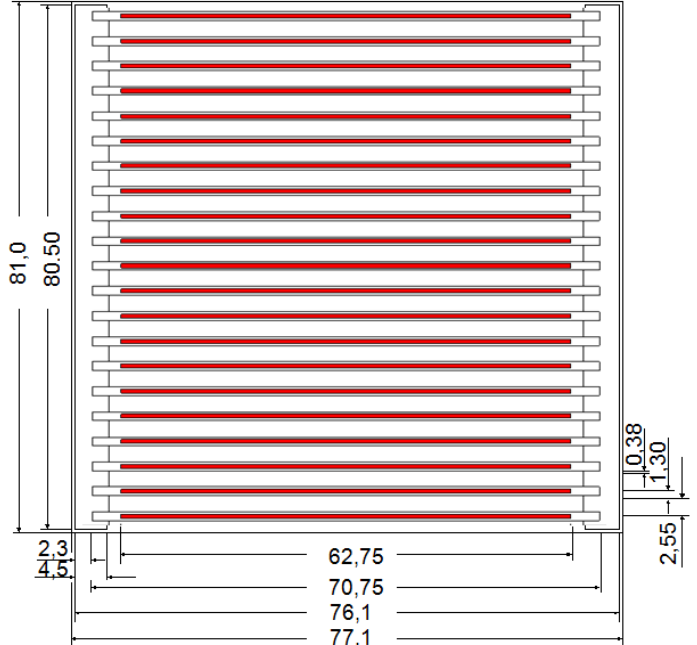

Figure 6 . The configuration of fuel plate

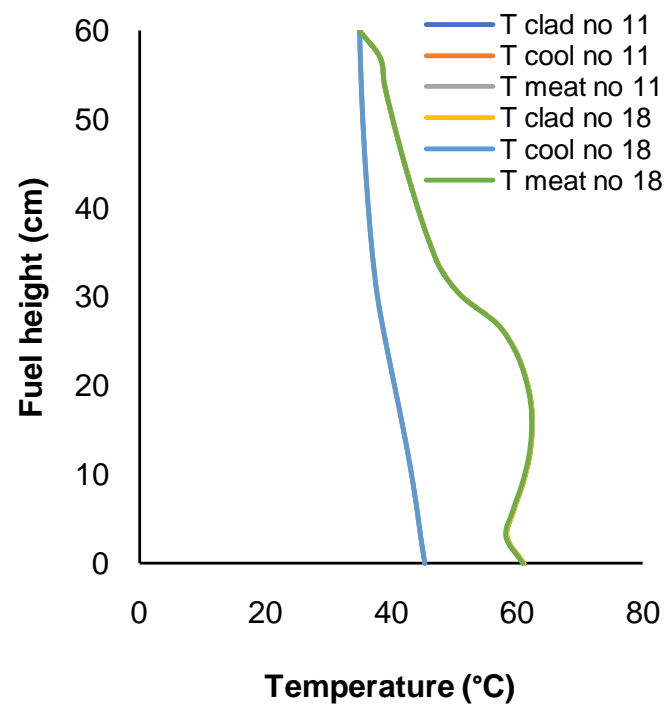

Figure 7. Comparison of thermal hydraulic parameters profile of Heathyd.

Based on the above analysis results, it is apparent that the use of thermohydraulic calculation codes at steady state condition with the same input, where uncertainty factor is neglected, produces similar trend lines of coolant, cladding, and fuel meat temperatures. Different modelling of thermohydraulic calculation at each code gives different output values. Each code used to calculation heat transfer in the MTR fuel type has its own sensitivity. Heathyd gives calculation results of coolant, cladding, and fuel meat temperature as well as safety margin at each channel and plate in a fuel 
element assembly. Heathyd only models heat transfer and hydrolics of fuel meat to coolant, along the fuel plate, without considering the entrance factor and outlet at the end fitting in accordance with the fuel element geometry. PARET-ANL code combines heat transfer equation and reactor point kinetic calculation. It can be used to compute heat transfer at steady state condition, but it is more sensitive if it is used for transient analysis. The heat transfer analysis results on fuel plate TRIGA show that the flow rate is $70 \mathrm{~kg} / \mathrm{s}$, which is consistent with the previous flow distribution calculation, implying inadequate coolant flow. To prevent dual flow or boiling from occurring, PARET-ANL gives the maximum power of $2 \mathrm{MW}$. Meanwhile, COOLOD-N2 takes into account fuel element geometry factor, and balance of heat, mass, and momentum. The analysis results show that
COOLOD-N2 and Heathyd code are sensitive in the steady state calculation benchmarked.

For comparison of the three-code analysis results in calculating the thermohydraulic parameters and reactor core safety at steady-state condition, Table 4 provides the thermohydraulic parameters comparison with those of RSG GAS. The thermohydraulic parameter and safety margin of RSG GAS in Table 4 has considered the uncertainty factor. The lower the $\Delta$ Temperature, indicating the adequacy of the coolant. likewise the greater the safety margin indicates the reactor is more safe. Comparing to the results of the RSG GAS calculation which has used the uncertainty factor, the value generated from the calculation of the sensitivity analysis of the three codes is fulfilled

Table 4. Comparison of key parameters to the RSG GAS.

\begin{tabular}{lcccc}
\hline \multicolumn{1}{c}{ Parameter } & RSG GAS & \multicolumn{3}{c}{ TRIGA Plate } \\
\cline { 2 - 5 } & COOLOD-N2 & COOLOD-N2 & HEATHYD & PARET-ANL \\
\hline Power, MW & 30 & 2 & 2 & 2 \\
Flow, kg/s & 800 & 70 & $3.7418 / F E$ & 70 \\
\% flow distribution to & 77 & 82 & 82 & 82 \\
active core & & & & 1.6990 \\
PPF axial max & 1.6 & 1.6990 & 1.6990 & 1 \\
PPF Radial max & 2.6 & 1 & 1 & 35 \\
Tin, ${ }^{\circ} \mathrm{C}$ & 40.5 & 35 & 35 & 52.53 \\
Tout, ${ }^{\circ} \mathrm{C}$ & 50.5 & 41.18 & 45.37 & 17.53 \\
$\Delta$ T in-out, $^{\circ} \mathrm{C}$ & 10 & 6.18 & 10.37 & 4.21 \\
Margin to onset of flow & 3.38 & 5.03 & 5.68 & - \\
instability & & & & 0.93 \\
V max, m/s & 3.6 & 0.96 & & \\
\hline
\end{tabular}

\section{CONCLUSION}

The sensitivity analysis on thermohydraulic codes used to calculate heat transfer in the fuel plate of TRIGA reactor at steady state condition indicates similar temperature trend lines for the coolant, plate, and fuel meat. Temperature calculation results obtained from COOLODN2, Heathyd and PARET ANL give consistent sensitivity with the differences of coolant temperature $2.83 \%$ up to $12.5 \%$; cladding temperature $2.14 \%$ up to $31.30 \%$; and fuel meat temperature $6.63 \%$ up to $18.64 \%$. Safety margins against to onset of flow instability for COOLOD-N2, Heathyd and PARET ANL, each are 5.03; 5.68 and 4.21 respectively. The three codes with their own sensitivity can be used to calculate MTR fuel plate research reactor 
thermohydraulic parameters. Heathyd can be used for detail analysis at each channel and plate in a fuel element assembly, while PARET-ANL is for steady state condition prior to transient, and COOLOD-N2 can be applied to both fuel plate and cylindrical fuel research reactor analysis at steady state condition.

\section{ACKNOWLEDGMENT}

The author would like to appreciate to the Management of PTRKN-BATAN. This research was funded from the PTRKN budget in fiscal year 2018.

\section{REFERENCES}

[1] S. Pinem, T. M. Sembiring, T. Surbakti, "Core conversion design study of TRIGA Mark 2000 Bandung using MTR plate type fuel element," International Journal of Nuclear Science and Technology, vol. 12, no. 3, pp. 222238, 2018.

[2] P. Basuki, P. I. Yazid, Z. Suud, "Neutronic design of plate type fuel conversion for Bandung TRIGA-2000 Reactor", International Journal of Nuclear Energy Science and Technology, vol. 15, no. 2, pp. 169180, 2014.

[3] I. Ramadhan, A. Suwono, "Preliminary study for design core of nuclear research reactor of TRIGA Bandung using fuel type of fuel element," International Journal of Engineering, vol. 14, no. 4, pp. 107-112, 2016.

[4] M. Subekti, D. Isnaini E. P. Hastuti, "The analysis of coolant-velocity distribution in plate-typed fuel element using CFD method for RSG-GAS research reactor," Jurnal Teknologi Reaktor Nuklir, vol. 15, no. 2, pp. 67-76, 2013.

[5] K. A. Sudjatmi, E. P. Hastuti, S. Widodo, "Analisis konveksi alam teras reaktor TRIGA berbahan bakar tipe pelat menggunakan COOLOD-N2," Jurnal.Teknologi Reaktor Nuklir, vol. 17, no. 2, pp. 67-78, 2015.

[6] E. P. Hastuti, M. Subekti, S. Dibyo, M. D. Isnaini, "Thermalhydraulic design and cooling system optimization of the high power inovative research reactor," Jurnal.Teknologi Reaktor Nuklir, vol. 17, no. 3, pp. 67-78, 2018

[7] E. P. Hastuti, S. Widodo, M. D. Isnaini, G. R. Sunaryo, S. Bakhri, "Determining coolant flow rate distribution in the fuelmodified TRIGA plate reactor," Journal of Physics: Conference Series, vol. 962, pp. 1-12, 2018.

[8] O. S. Al-yahia, H. Lee, D Jo, "Transient analyses of the Jordanian $5 \mathrm{MW}$ research reactor under LOEP accident," Annals Nuclear Energy, vol. 87, pp. 575-83, 2016.

[9] K. Ardaneh, S. Zaferanlouei, "An analytical solution for thermal-hydraulic analysis and safety margins in MTRtype research reactors cooled by natural convection," Annals Nuclear Energy, vol. 51, pp. 282-8, 2013.

[10] O. S. Al-Yahia, M. A. Albati, J. Park, H. Chae, D. Jo, "Transient thermal hydraulic analysis of the IAEA $10 \mathrm{MW}$ MTR reactor during loss of flow accident to investigate the flow inversion," Annals Nuclear Energy, vol. 62, pp. 144-52, 2013.

[11] E. P. Hastuti, T. Surbakti, S. Widodo, Sudarmono, "Abnormal control rod withdrawal analysis for innovative research reactor using PARET-ANL codes," Kerntechnik, vol. 83, no. 2, pp. 96-105, 2018

[12] R. Nasir, S. M. Mirza, N. M. Mirza, "Progress in Nuclear Energy Study of successive ramp reactivity insertions in typical pool-type research reactors," Progress in Nuclear Energy, vol. 66, pp.115-23, 2013. 